\title{
Kalanchoe winteri Gideon F.Sm., N.R.Crouch \& Mich.Walters (Crassulaceae), a new species from the Wolkberg Centre of Endemism, South Africa
}

\author{
Neil R. Crouch ${ }^{1,2}$, Gideon F. Smith ${ }^{3,4}$, Michele Walters ${ }^{5,6}$ \\ \& Estrela Figueiredo ${ }^{3,4}$
}

1. Biodiversity Research, Assessment and Monitoring, South African National Biodiversity Institute, P.O. Box 52099, Berea Road, 4007 South Africa (email: N.Crouch@sanbi.org.za).

2. School of Chemistry and Physics, University of KwaZulu-Natal, Durban 4041, South Africa.

3. Department of Botany, P.O. Box 77000, Nelson Mandela Metropolitan University, Port

Elizabeth, 6031 South Africa (email: smithgideon1@gmail.com; epnfigueiredo@gmail.com).

4. Centre for Functional Ecology, Departamento de Ciências da Vida, Universidade de Coimbra, 3001-455 Coimbra, Portugal.

5. Natural Resources and Environment, Council for Scientific and Industrial Research, P.O. Box 395, Pretoria, 0001 South Africa (email: mwalters@csir.co.za).

6. Centre for Wildlife Management, University of Pretoria, Pretoria 0002, South Africa.

Summary: A new Kalanchoe species, K. winteri Gideon F.Sm., N.R.Crouch \& Mich.Walters, is described from rocky grasslands of the Wolkberg region of Limpopo province, South Africa. The species is closely allied to both $K$. thyrsiflora Harv. and K. luciae Raym.-Hamet, from which it is readily separable on vegetative and reproductive characteristics.

Zusammenfassung: Eine neue Kalanchoe-Art, $K$. winteri Gideon F. Sm., N. R. Crouch \& Mich.Walters, wird aus felsigen Grasländern der Wolkberg-Region in der Provinz Limpopo, Südafrika, beschrieben. Die Art ist nah mit $K$. thyrsiflora Harv. und K. luciae Raym.-Hamet verwandt, von denen sie leicht durch vegetative und generative Merkmale unterschieden werden kann.

\section{Introduction}

In southern Africa the essentially Old World genus Kalanchoe Adans. occurs primarily in the summer-rainfall savanna region, being largely absent from the succulent-rich winter-rainfall and arid karroid districts (Smith et al., 2003). Kalanchoe is included in Crassulaceae tribe Kalanchoeae t'Hart (1995: 167) along with Cotyledon L. and Bryophyllum Salisb. The split of Bryophyllum from Kalanchoe sensu stricto is still under debate and a detailed study is required to understand Kalanchoe as a whole, and resolve fully the boundaries of these two genera
(Eggli et al., 1995; Descoings, 2003). Most recently, Thiede \& Eggli (2007) treated Bryophyllum as a section of Kalanchoe. Chernetskyy (2012) argued that the existence of "intermediate" species makes it impossible to distinguish separate genera, a notion earlier supported by Mort et al. (2001) who had recommended that Bryophyllum be included in Kalanchoe, based on strong support from MATK sequence analyses. Whereas Bryophyllum taxa occur in Madagascar only, representatives of Kalanchoe sensu stricto occur throughout Africa, Madagascar, Arabia, and Asia, with particularly high species diversity in south-central and eastern Africa.

There are approximately 15 Kalanchoe species indigenous to southern Africa. The last upheld Kalanchoe species described from the Flora of Southern Africa (FSA) region was K. neglecta Toelken from Maputaland (Tölken, 1978). Inexplicably, Raymond-Hamet, renowned specialist of Crassulaceae, especially of the genera Kalanchoe and Sedum L., had not validly published a number of the names for his concepts by the time of his death in 1972. Accordingly, Tölken (1978) re-evaluated these, formalising some and conferring subspecies status on $K$. montana Compton, as K. luciae subsp. montana (Compton) Toelken. Subsequently, a further species has been discovered by Pieter Winter, who gathered it whilst botanising the Wolkberg to the south of Haenerstburg in South Africa's Limpopo 


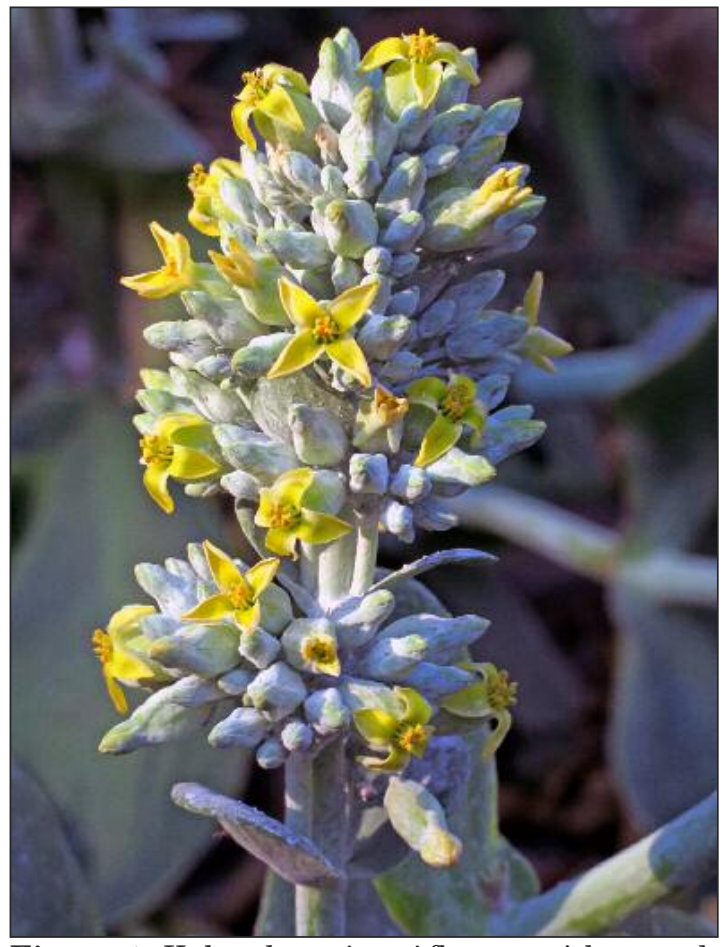

Figure 1. Kalanchoe winteri flowers with spreading to reflexed yellow corolla lobes that are characteristically much longer than broad and have inrolled margins and a truncate apex. Both lower and upper anther ranks are exserted.

Photograph: Neil R. Crouch.

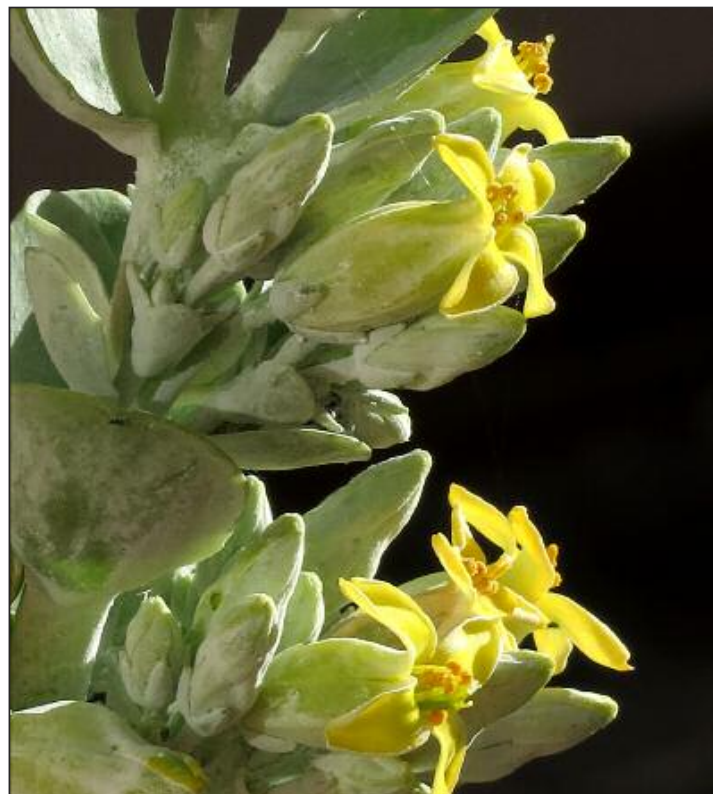

Figure 3. The 4-angled corolla tubes of Kalanchoe winteri are subtended by relatively short calyx lobes.

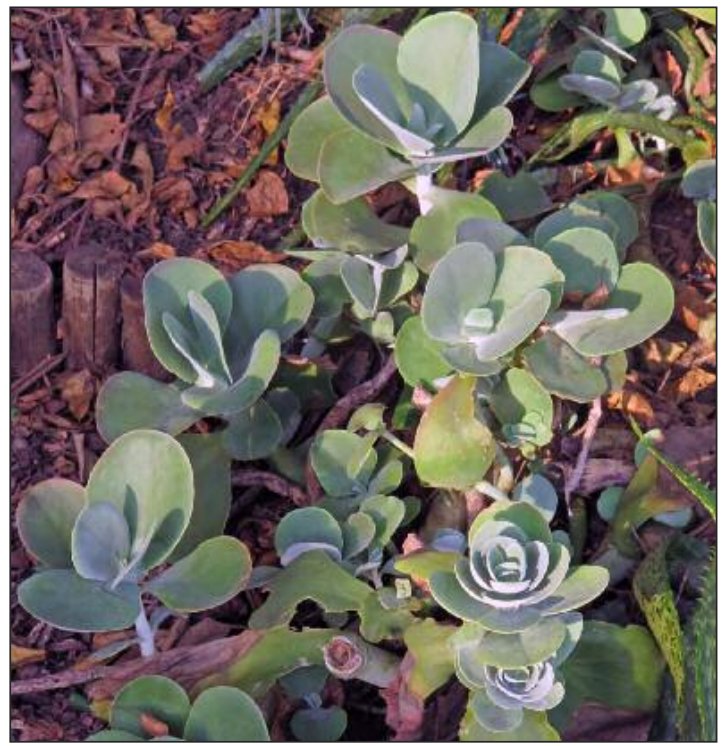

Figure 2. The leaves of Kalanchoe winteri spread more widely than in both $K$. thyrsiflora and $K$. luciae, and are less densely packed towards the base. All plant parts are covered in a highlyscented powdery bloom that is resinous to the touch, and persists even on old leaves. Plants are not monocarpic, rather resprouting from the base annually. Leaf margins are occasionally red-infused, but never the entire lamina.

Photograph: Neil R. Crouch.

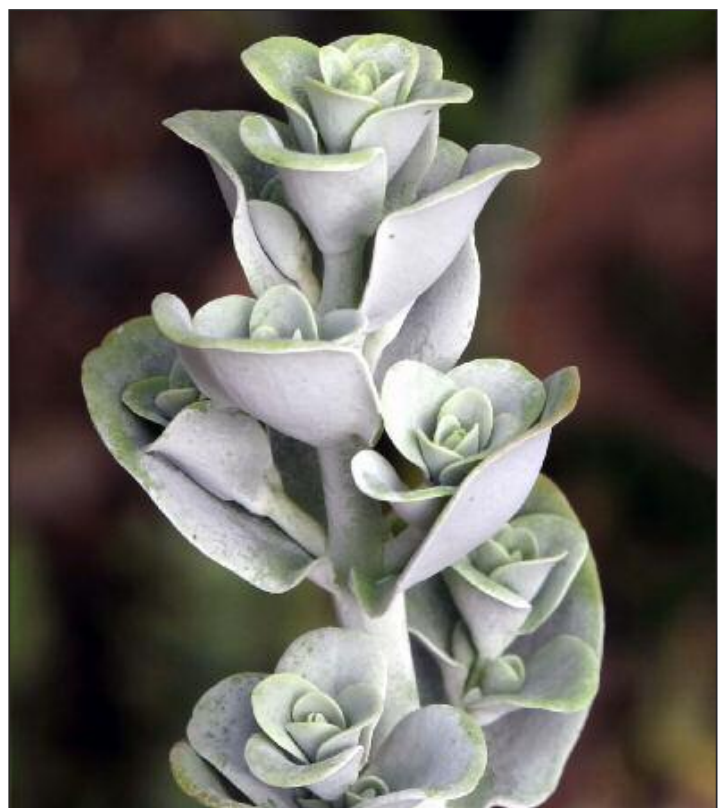

Figure 4. Lateral shooting is a commonly observed in Kalanchoe winteri, particularly after release from apical dominance.

Photograph: Neil R. Crouch. 


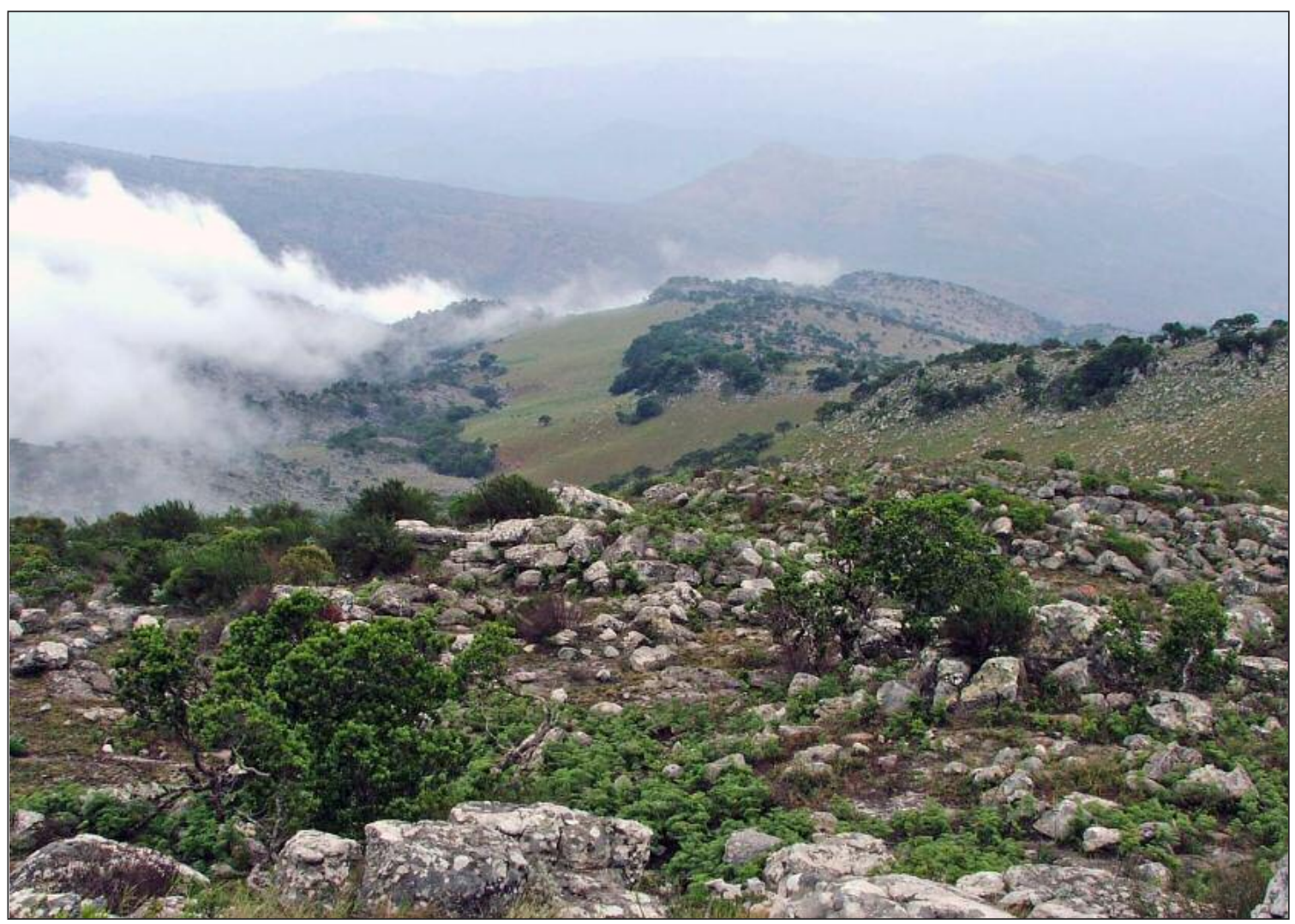

Figure 5. Northern Escarpment Quartzite Sourveld habitat of Kalanchoe winteri, Wolkberg, Limpopo province, South Africa.

Photograph: Mervyn Lötter.

province. We here describe and illustrate this new species (Figures 1-4), as Kalanchoe winteri Gideon F.Sm., N.R.Crouch \& Mich.Walters.

\section{Taxonomy}

Kalanchoe winteri Gideon F.Sm., N.R.Crouch \& Mich.Walters sp. nov.

Type: South Africa. Wolkberg, Limpopo province, Thabakgolo Escarpment, Sedibeng sa Lebese Mountain, West of Strasburg. P.J.D. Winter 4430, 10 September 2000. (holo- PRE; iso- BNRH, PRU).

Diagnosis: Kalanchoe winteri differs from $K$. luciae in consistently having golden yellow instead of whitish, pale yellowish-green, or pale pink corolla lobes, ellipsoid rather than urceolate corolla tubes, and leaf blades that are occasionally red-infused on their margins rather than frequently throughout. It differs from $K$. thyrsiflora in having ellipsoid corolla tubes instead of cylindrical ones, a corolla lobe length-to-breadth ratio of 2 rather than 1, filaments inserted lower in the corolla tube, and all eight anthers exserted instead of only four. $K$. winteri differs from both $K$. luciae and $K$. thyrsiflora in presenting sometimes distinctly auriculate, mainly wide-spreading rather than erect leaves, and ovaries that are broadest above their middle rather than at this mid-locus.

Description: Perennial, many-leaved, 1-3 rosettes, sparsely to profusely branched from near the base and higher up, smooth, waxy, robust succulent, $0.5(-0.9) \mathrm{m}$ tall in bloom. Stems erect to leaning and curved upwards, smooth, waxy especially at internodes, light green. Leaves opposite, erect to mostly spreading to variously floppy, succulent, sessile, flattened above and below, glabrous, waxy, light green to bluish-green; petiole absent; blade 140-160 × 80-140cm, obovate to somewhat oblong, not folded lengthwise, occasionally light red-infused; axils often carrying small leafy shoots and short branches that produce flowers in season; base narrow, sometimes distinctly auriculate; apex rounded-obtuse or truncate, usually indented at the tip; margins smooth, slightly lighter green than blade, sometimes infused with red. Inflorescence a slender, erect, densely flowered, cylindrical thyrse consisting of several dichasia terminating in monocha- 


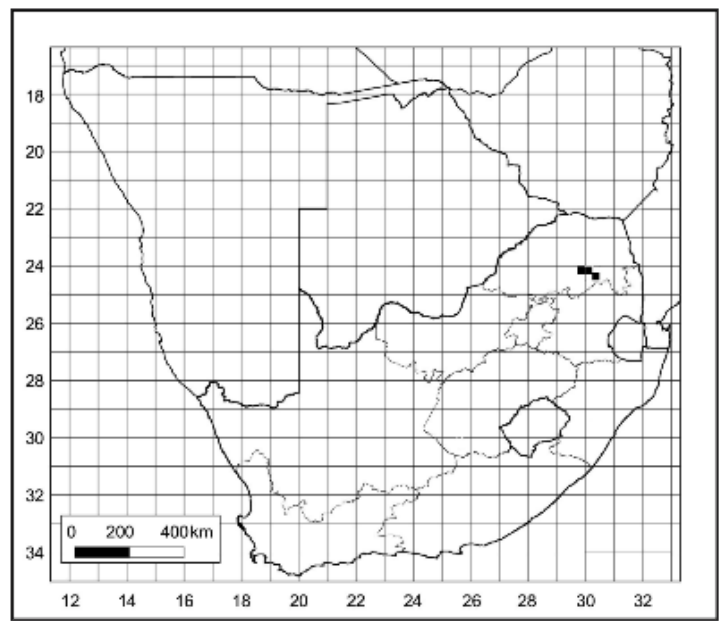

Figure 6. Known geographical distribution range of Kalanchoe winteri in South Africa.

sia, 0.5(-0.9)m tall. Flowers $13-15 \mathrm{~mm}$ long, erect to slanted horizontally, pale yellowish-green to greenish-white (tube) and yellow (lobes), all parts excepting tepal lobes above covered with a substantial white waxy bloom, highly scented, resinous to the touch; pedicels $9-10 \mathrm{~mm}$ long. Calyx mid-green, contrasting against lighter green corolla tube; sepals 4, 3-4mm long, elongated-triangular, acute (sharp-tipped). Corolla light greenish-yellow, tube 11-12 mm long, more or less quadrangular, ellipsoid (cigar-shaped, enlarged in the middle), distinctly 4-angled, lobes 6$8 \times 3.5-4.0 \mathrm{~mm}$, triangular, margins slightly to distinctly inrolled, truncated, bright yellow. Stamens 8 , inserted just below or in the middle of the corolla tube, $1-2 \mathrm{~mm}$ exserted; filaments 3.0$5.5 \mathrm{~mm}$ long, thin, light greenish-white; anthers $1.4-1.6 \mathrm{~mm}$ long, yellow. Pistil pyriform, consisting of 4 carpels; ovaries 9-10mm long, light green; styles $\pm 4 \mathrm{~mm}$ long; stigmas very slightly capitate, light yellow, exserted as far as or slightly less than anthers; scales $2.3-2.5 \times 1.8-2.1 \mathrm{~mm}$, narrowing at the base, truncate, repand. Follicles not seen. Seeds not seen. Chromosome number: unknown.

Eponymy: This species is named for the collector of the type, Pieter Jacobus de la Rey Winter (1964-), a South African botanist working in Cape Town at the Compton Herbarium of the South African National Biodiversity Institute. Previously he was the Curator of the L.C. Leach Herbarium of the University of Limpopo, in Polokwane, South Africa.

Flowering time: May-September, peaking in July.

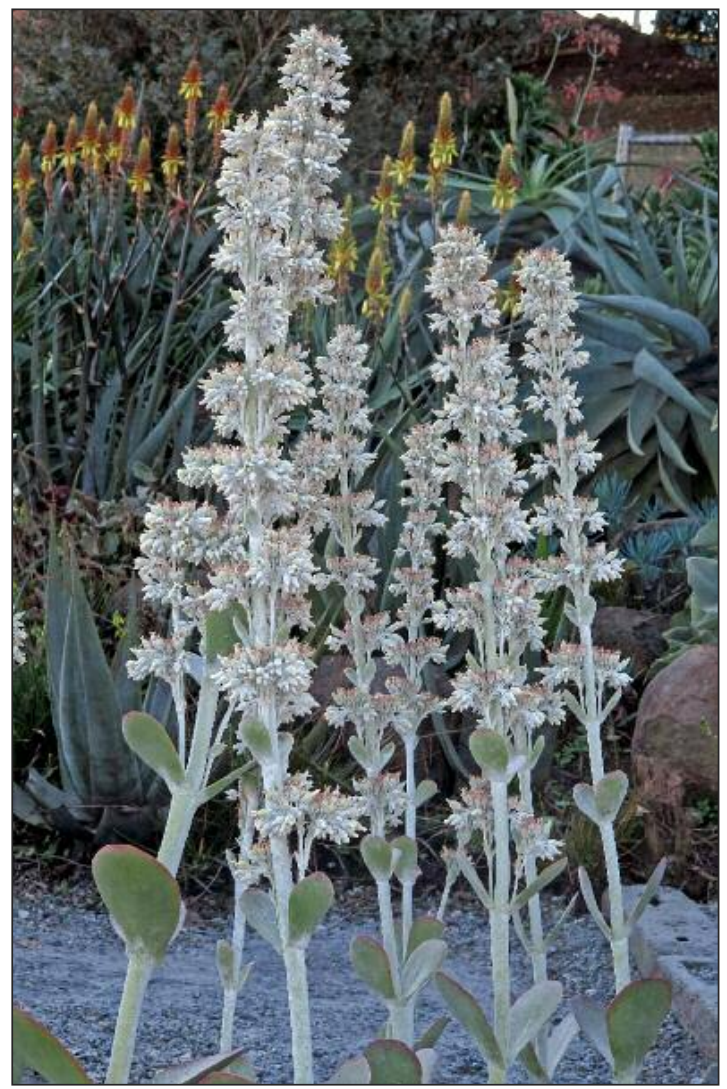

Figure 7. The axillary cymes comprising the thyrses of Kalanchoe luciae subsp. luciae are often well spaced to produce interrupted inflorescences.

Photograph: Neil R. Crouch.

Distribution and ecology: Kalanchoe winteri occurs in the Limpopo Province of South Africa where it has been observed growing at three different localities over a $50 \mathrm{~km}$ range. It occurs in Northern Escarpment Quartzite Sourveld (Mucina et al., 2006) (Figure 5), growing on quartzite in grassland vegetation, always in fire protected microhabitats on or near rocks. It may be encountered at altitudes of $1370-1750 \mathrm{~m}$ above sea level on north, northeastern, eastern, and southwestern aspects, usually in full sun, although at times in the partial shade of shrubs. This species is largely restricted to the Wolkberg (Figure 6), part of the mountain chain that forms the northern Drakensberg escarpment, and located to the immediate southwest of the town of Haenertsburg. The Wolkberg range is included in a broader area that has been recognised as the Wolkberg Centre of Endemism; the new species occurs in the Serala Subcentre of this Centre (A.E. [Braam] van Wyk, personal communication). More than 130 endemic or near-endemic taxa of 


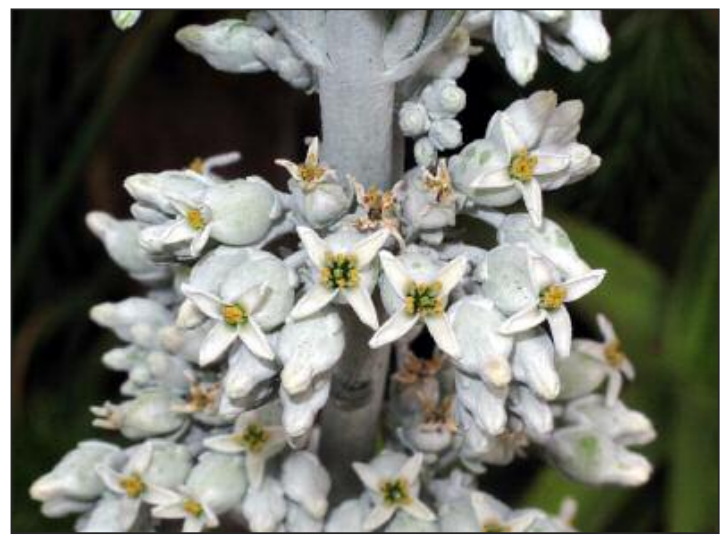

Figure 8. Flowers of Kalanchoe luciae subsp. luciae have corolla lobes longer than broad but which are whitish to greyish-green, never bright yellow as in $K$. winteri and $K$. thyrsiflora. The corolla tubes of $K$. luciae are urceolate, and both anther ranks and stigmas are exserted.

Photograph: Neil R. Crouch.

which almost $20 \%$ are succulents (Van Wyk \& Smith, 2001) have been recorded for the Wolkberg Centre. Amongst these are Aloe nubigena Groenew., Brachystelma stellatum E.A.Bruce \& R.A.Dyer, and Euphorbia excelsa A.C.White, R.A.Dyer \& B.Sloane. Other plant associates include Protea caffra Meisn., Rapanea melanophloeos (L.) Mez, and Aloe cf. affinis A.Berger. A colony of Leucospermum saxosum S.Moore is in close proximity to the type locality. Whilst neither K. luciae (Figures 7-9) nor K. thyrsiflora (Figures 10 \& 11) were observed growing in the immediate vicinity, they are known to grow on dolomite about $5 \mathrm{~km}$ distant from a $K$. winteri location. Flowering periods for these taxa overlap.

In a Pretoria garden the flowers are visited regularly by carpenter bees, Xylocopa cf. caffra, and in a Durban garden occasionally by Apis mellifera, the African honey bee. Plants in habitat attain a height of $\pm 0.5 \mathrm{~m}$ when flowering, but are usually taller when cultivated under optimum conditions; this may be attributable to edaphic factors as soils of the Northern Escarpment Quartzite Sourveld are reported to be nutrientpoor (Mucina et al., 2006).

Discussion: Among the southern African Kalanchoe taxa that bear densely-flowered, near-cylindrical thyrses, $K$. winteri is the only species with pyriform pistils (Figure 12). This species may be confused with $K$. thyrsiflora and $K$. luciae. However, by its golden yellow corolla lobes and ellipsoid corolla (Figures 1 \& 3) it may be separated from K. luciae (Table 1) (Figure 8). From K. thyr-

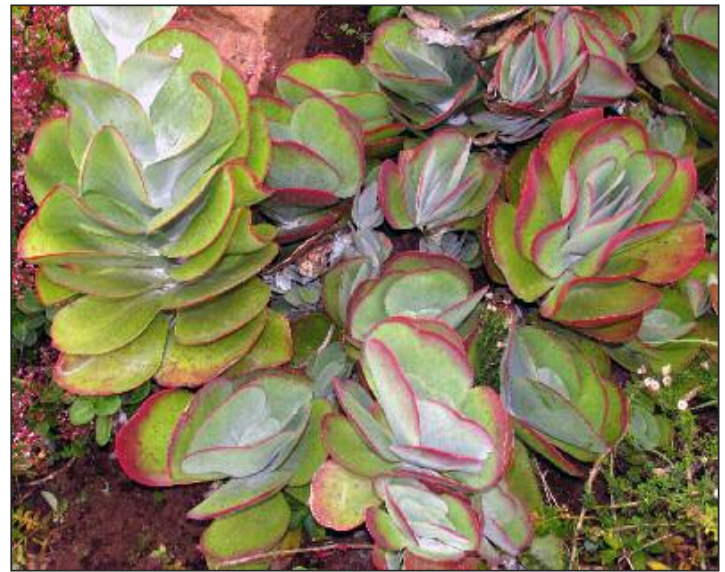

Figure 9. The basal leaf rosettes of Kalanchoe luciae present suberect leaves that bear attractive red-margins. The older outer leaves of these rosettes have lost much of their white mealy bloom. Photograph: Neil R. Crouch.

siflora (Figure 11) it differs in having a less cylindrical and more 4-angled tube, oblong rather than square corolla lobes, the lower filament rank inserted deeper in the corolla tube (corresponding to $\pm 3 / 4$ way up the tube), and scales broader. The leaves of $K$. winteri are much less red-infused than those of $K$. thyrsiflora, and particularly less so than $K$. luciae (Figure 13). In this group within Kalanchoe the outer corolla colour appearance varies with the extent to which a whitish bloom is present; in K. luciae subsp. montana this is frequently absent or obsolescent, whereas in $K$. thyrsiflora, $K$. winteri, and $K$. luciae subsp. luciae the corolla may appear greyish-white when the bloom is intense.

The key to southern African species of Kalanchoe that produce an elongated, dense, more or less cylindrical thyrse (species 12 and 13 of Tölken, 1985: 61) now becomes:

Corolla lobes whitish, pale pinkish or pale yellowish-green, rarely yellow;

Plants glabrous; calyx lobes $2.5-4.0 \mathrm{~mm}$

long ................................. luciae subsp. luciae Plants hairy; calyx lobes $5-7 \mathrm{~mm}$ long

K. luciae subsp. montana

Corolla lobes bright golden yellow;

Corolla lobes squarish, to $3 \mathrm{~mm}$ long; corolla tube cylindrical, not contracted below mouth; 4 anthers exserted ........................ thyrsiflora Corolla lobes triangular, $>6 \mathrm{~mm}$ long; corolla tube ellipsoid (cigar-shaped), slightly contracted below mouth; 8 anthers exserted ........ K. winteri 
Table 1. Main diagnostic characters separating Kalanchoe winteri from close relatives in the FSA region (cf. Wood \& Evans, 1899; Compton, 1967; Fernandes, 1983; Tölken, 1985).

\begin{tabular}{|c|c|c|c|c|}
\hline \# & Character & $\begin{array}{l}\text { Kalanchoe } \\
\text { luciae }\end{array}$ & $\begin{array}{l}\text { Kalanchoe } \\
\text { winteri }\end{array}$ & $\begin{array}{l}\text { Kalanchoe } \\
\text { thyrsiflora }\end{array}$ \\
\hline 1 & Bloom on mature leaves & Absent & Persists & Sometimes persists \\
\hline 2 & Leaf vestiture & Glabrous or hairy & Glabrous & Glabrous \\
\hline 3 & Calyx lobe length (mm) & $4-6(-7)$ & $3-4$ & $2.5-4.0$ \\
\hline 4 & Corolla tube length (mm) & $\begin{array}{l}6-10(-12) \\
\text { (diam. in middle } \\
\text { about 8) }\end{array}$ & $\begin{array}{l}11-12 \\
\text { (diam. in middle } \\
\text { about } 6.5 \text { ) }\end{array}$ & $\begin{array}{l}12-16(-20) \\
\text { (diam. in middle } \\
\text { about } 6.5)\end{array}$ \\
\hline 5 & Corolla tube shape & $\begin{array}{l}\text { Urceolate } \\
\text { (urn-shaped) }\end{array}$ & $\begin{array}{l}\text { Ellipsoid } \\
\text { (cigar-shaped) }\end{array}$ & Cylindrical \\
\hline 6 & $\begin{array}{l}\text { Corolla tube contraction } \\
\text { at mouth }\end{array}$ & Very contracted & Slightly contracted & $\begin{array}{l}\text { Slightly contracted } \\
\text { or not so }\end{array}$ \\
\hline 7 & Corolla lobe colour above & $\begin{array}{l}\text { Whitish, pale yellowish } \\
\text {-green, pale pink, } \\
\text { yellowish-green }\end{array}$ & Bright yellow & $\begin{array}{l}\text { Bright yellow to } \\
\text { orange-yellow }\end{array}$ \\
\hline 8 & Corolla lobe length (mm) & $4-6(-7)$ & $6-8$ & $2-3$ \\
\hline 9 & $\begin{array}{l}\text { Corolla lobe } \\
\text { length/width ratio }\end{array}$ & \pm 2 & \pm 2 & \pm 1 , lobe almost square \\
\hline 10 & Corolla lobe apex & $\begin{array}{l}\text { Acute to obtuse, } \\
\text { sometimes apiculate }\end{array}$ & Acute, truncated & Obtuse to rounded \\
\hline 11 & Filament length (mm) & $4-5$ & $\pm 3.0-5.5$ & $\leq 2$ \\
\hline 12 & $\begin{array}{l}\text { Filament insertion } \\
\text { position in corolla tube }\end{array}$ & $\pm 3 / 4$ way up & $\pm 3 / 4$ way up & Just below mouth \\
\hline 13 & Anther exsertion & All 8 & All 8 & Only 4 \\
\hline 14 & Pistil shape & $\begin{array}{l}\text { Prolate } \\
\text { (rugby ball-shaped) }\end{array}$ & $\begin{array}{l}\text { Pyriform } \\
\text { (pear-shaped) }\end{array}$ & $\begin{array}{l}\text { Narrowly barrel- } \\
\text { shaped }\end{array}$ \\
\hline 15 & Ovary form & Broadest $1 / 2$ way up & Broadest $2 / 3$ way up & Broadest $1 / 2$ way up \\
\hline 16 & Style length (mm) & $2.75-3.50$ & \pm 4 & $(1.5-) 2.5-3.0$ \\
\hline
\end{tabular}

\section{Acknowledgements}

Curators of $\mathrm{CPF}, \mathrm{NH}, \mathrm{NU}$, and PRE are thanked for making facilities available during this study, and Mervyn Lötter kindly allowed use of his habitat photograph of the Wolkberg.

Anonymous referees are thanked for their constructive comments.

\section{References}

CheRnETSKYY, M.A. (2012). The role of morphoanatomical traits of the leaves in the taxonomy of Kalanchoideae Berg. subfamily (Crassulaceae DC.). Modern Phytomorphology 1: 15-18.
Compton, R.H. (1967). Plantae novae Africanae. Series XXXII. J. S. Afr. Bot. 33: 293-304.

Descoings, B. (2003). Kalanchoe. In: U. EgGLI (ED.), Illustrated handbook of succulent plants: Crassulaceae. Pp. 143-181. Springer-Verlag, Berlin.

EgGli, U., 'T HART, H. \& NyfFEleR, R. (1995). Toward a concensus classification of the Crassulaceae. In: H. 'T HART \& U. EGGLI (EDS), Evolution and systematics of the Crassulaceae. Pp. 173-192. Backhuys Publishers, Leiden.

Fernandes, R.[B.] (1983). Crassulaceae. In: E. LAUnert (ED.), Fl. zam. 7(1): 3-71. Managing 


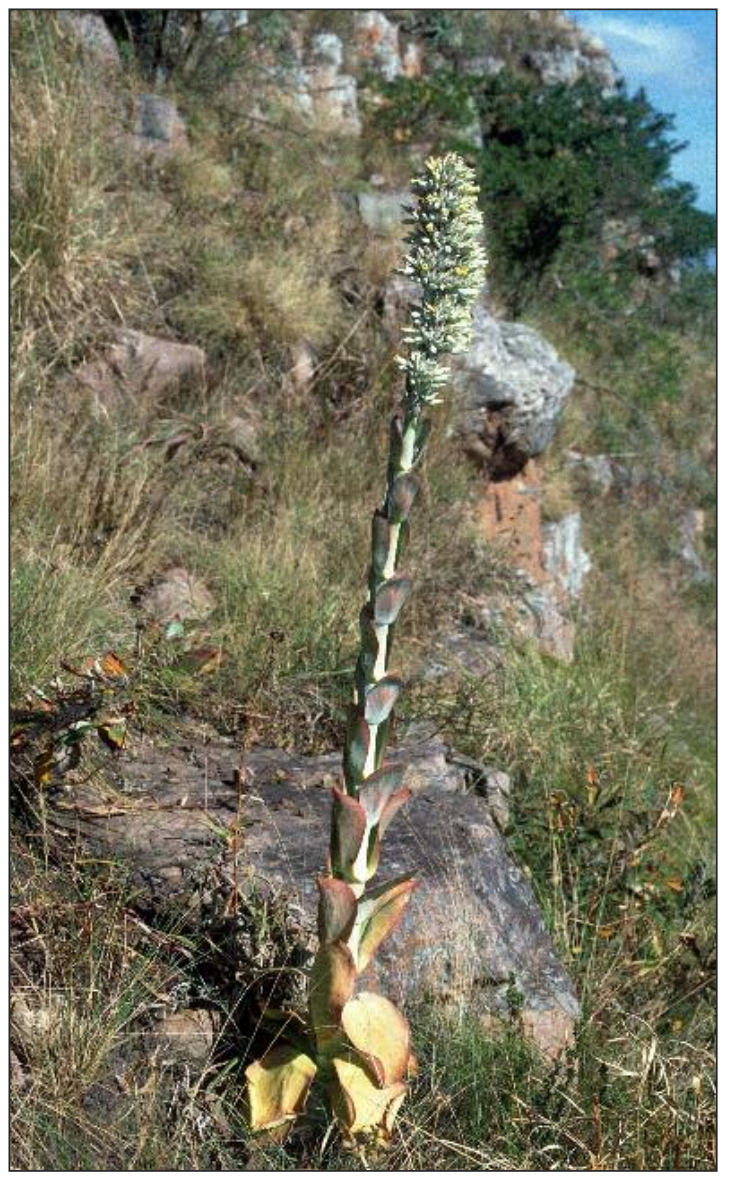

Figure 10. Flowering plant of Kalanchoe thyrsiflora with a single stem arising from the basal rosette of the previous year.

Photograph: Neil R. Crouch.

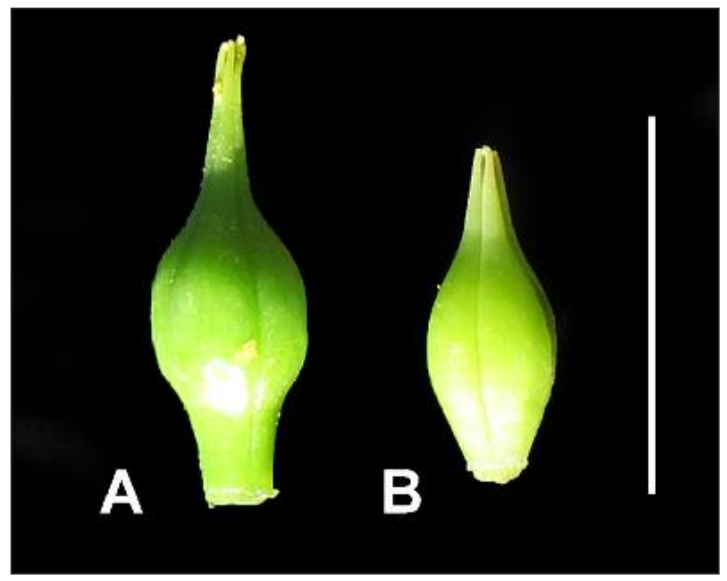

Figure 12. Pistils of Kalanchoe winteri (A) and K. luciae subsp. luciae (B), pyriform and prolate respectively. Scale bar: $10 \mathrm{~mm}$.

Photograph: Neil R. Crouch.

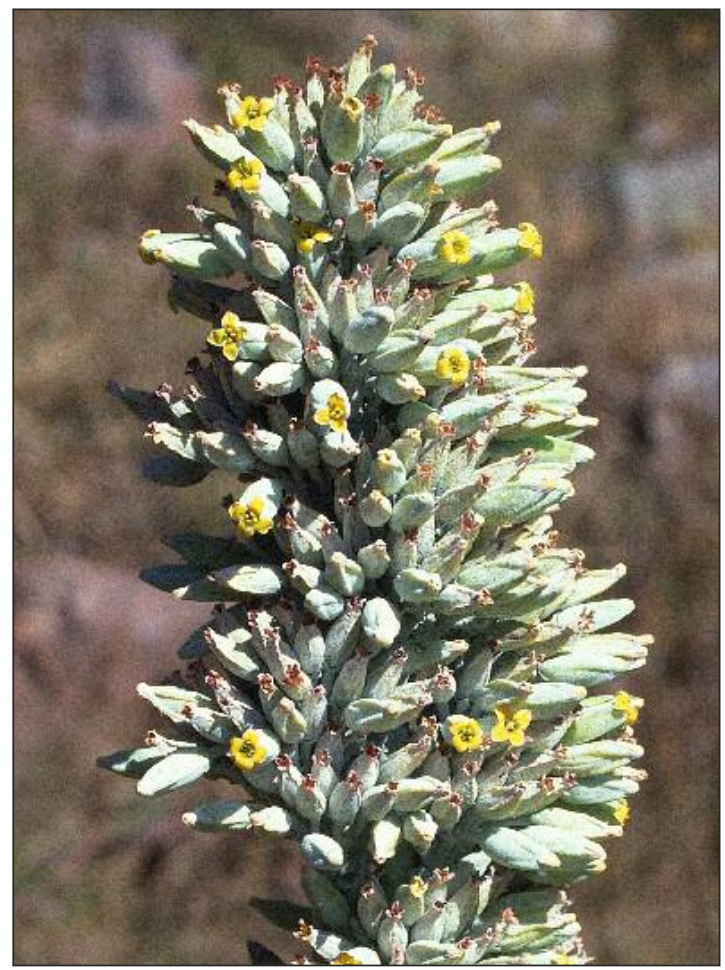

Figure 11. Section of the tight packed inflorescence of Kalanchoe thyrsiflora revealing flowers with characteristic cylindrical corolla tubes and yellow, short, squarish corolla lobes. Only the upper anther rank is exserted.

Photograph: Neil R. Crouch.

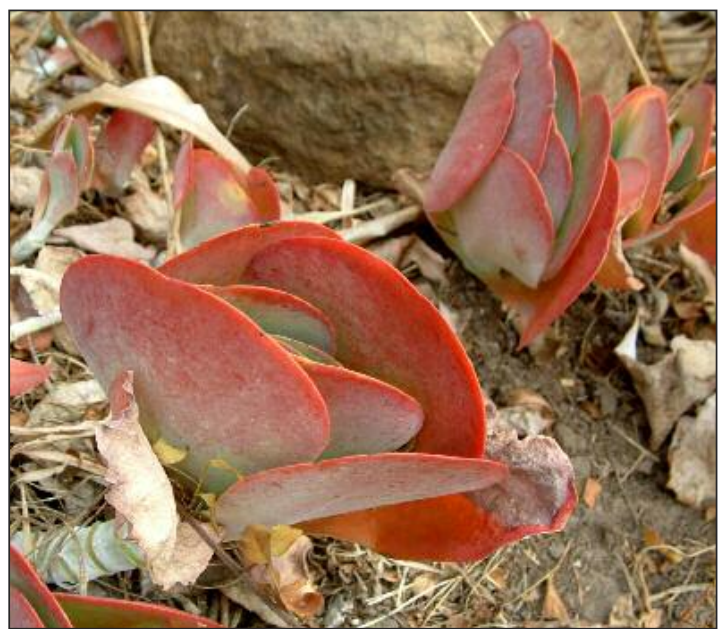

Figure 13. Under high stress growing conditions the leaves of $K$. luciae turn almost uniformly red. Photograph: Neil R. Crouch. 
Committee on behalf of the contributors to Flora zambesiaca, London.

Mort, M.E., Soltis, D.E., Soltis, P.S., FranciscoOrtega, J., \& Santos-Guerra, A. (2001). Phylogenetic relationships and evolution of Crassulaceae inferred from MATK sequence data. Amer. J. Bot. 88: 76-91.

Mucina, L., Hoare, D.B., Lötter, M.C., Du Preez, J., Rutherford, M.C., ScotT-Shaw, C.R., BreDEnKamp, G.J., Powrie, L.W., ScotT, L., CAMP, K.G.T., Cilliers, S.S., Bezuidenhout, H., Mostert, T.H., Siebert, S.J., Winter, P.J.D., Burrows, J.E., Dobson, L., Ward, R.A., Stalmans, M., Oliver, E.G.H., Siebert, F., Schmidt, E., Kobisi, K. \& Kose, L. (2006). Grassland Biome. In: L. Mucina \& M.C. RUTHERFord (EDS), The vegetation of South Africa, Lesotho and Swaziland. Strelitzia 19: 349-436.

Smith, G.F., Crouch, N.R. \& Steyn, E.M.A. (2003). Notes on the distribution and ethnobotany of Kalanchoe paniculata (Crassulaceae) in southern Africa. Bradleya 21: 21-24.
'T HART, H. (1995). Chapter 10. Infrafamilial and generic classification of the Crassulaceae. In: H. 'T HART, \& U. EGGLI (EDS), Evolution and systematics of the Crassulaceae. Pp. 159-172. Backhuys Publishers, Leiden.

Thiede, J. \& EgGLI, U. (2007). Crassulaceae. In: K. KuBITZKI (ED.), The families and genera of vascular plants. IX. Flowering plants. Eudicots: 83-118. Springer-Verlag, Berlin.

TölkEN, H.R. (1978). Two new species and a new combination in the genus Kalanchoe. J. S. Afr. Bot. 44: 89-91.

Tölken, H.R. (1985). Crassulaceae. In: O.A. LeIsTNER (ED.), Fl. S. Afr. 14: 1-244. Botanical Research Institute, Pretoria.

VAN WyK, A.E. [BRAAM] \& SMITH, G.F. (2001). Regions of floristic endemism in southern Africa. $A$ review with emphasis on succulents. Umdaus Press, Hatfield, Pretoria.

Wood, J.M. \& Evans, M. (1899). Kalanchoe thyrsiflora Harv. Natal plants. Volume 1: 43, t. 52. 